\title{
Time to Ride the Wave of Precision Medicine
}

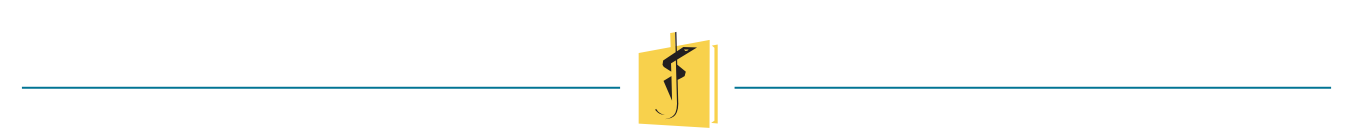

\author{
Raymond L. Rosales, Editor-in-Chief
}

Almost a decade has passed since we first heard about Precision Medicine [1] from the National Research Council, USA. With more technology, expertise and understanding, the time has come for the Philippines to stop watching and instead, ride this tide of change, with the patient at the center.

The underlying concept of Precision Medicine is that disease treatment and prevention for individual patients are tailored on the basis of variability in genes, lifestyle and environment [2]. There are new technologies and expertise to look for patterns of effective treatments with targeted. It has genetic variations in subsets of patients. This means not just the traditional taking of personal profiles, medical and life histories, and patient preferences but also the effective use of electronic health records, genetic testing, big data analytics, and supercomputing - for the clinician to practice truly precise medicine [3].

Parallel and contributing to the application of Precision Medicine is the advent of Personalized Medicine. At the core is the patient who is no longer considered a part of a cohort, expected to respond to medication with some degree of uniformity and placed into a p-value, for significance. Patients are now participative in decision-making on treatment directions. Input and feedback from relevant specialists, paramedical personnel, even caregivers and relatives are welcomed in order to achieve desired treatment outcomes (so-called Inter-disciplinary/Multi-disciplinary team approach)

Patient data gives power to Precision Medicine. Clinical records and genetic attributes of patients and healthy volunteers become material in research, the results of which, influence individualized health care and further clinical studies. While patients could trust their clinicians and be persuaded to share their medical records, it is crucial that Data Privacy and Anonymity are protected. As more patient data are collected in large, multi-centered data banks, the formidable challenge is therefore in securing resource sharing.

Why do we need to get out of our comfort zones and join the increasing trend of Precision Medicine, particularly in the Asia-Pacific? The answer: Increasing patient population with chronic diseases and high cost of both treatment and informal care.

Asia-Pacific has a current estimated population of $4.3 \mathrm{~B}$, which is $60 \%$ of the world population with a growth rate of about 0.96 per year [4]. Eleven percent of that or $473 \mathrm{M}$ are estimated to be seniors - aged 60 years and above $[5,6]$. By 2050, the senior population is expected to rise by $25 \%$. There is a significant subset to this: the oldest of the old meaning aged 80 years and above - are increasing in population as well in the Asia-Pacific. In 1990, they were $0.8 \%$ and in 2012 , they were $1.4 \%$ or $61.6 \mathrm{M}$ out of $440 \mathrm{M}$ seniors. By 2050 , it is projected to increase by a staggering $4.4 \%$ [7].

Chronic diseases typically surface with the increasing senior population. The cost of diagnosis and treatment will keep on increasing. In mid-to-low income countries, informal care (unpaid caregivers), social care (community and residential care) and medical care, a uniform standard of care may not 
be practiced, as such, the cost will vary and could be very large. Through the application of new technologies, diagnosis and treatment will be more efficient and cost-effective.

Let us get ready, let us learn and further understand how we can apply Precision Medicine in our approach to diagnosis and treatment. Let us collaborate with international institutions and clinicians who are currently involved in research that uses the tools of Precision Medicine.

We are hopeful that not too long from now, JMUST will be publishing articles that contribute to the body of knowledge in Precision Medicine, particularly in the Asia-Pacific.

In this third issue of JMUST, we have fully implemented our digital authoring platform and by using a dedicated electronic, publicly-accessible platform, we have joined the ranks of many established international scientific and medical journals.

We welcome all our readers to JMUST's 10 articles: 5 of them are clinical or observational studies, 2 are case reports, 1 meta-analysis, 1 qualitative research on medical students, 1 on medical education, and this editorial. The wings of JMUST are getting stronger with more than 50 articles submitted per issue. We thank all the authors for taking the opportunity to research and publish. We are truly grateful for the continued belief in and support of our work in JMUST by USTFMS and USTH. The peer reviewers, associate editors and staff are exemplary in their dedication as always. 


\section{REFERENCES:}

1. National Research Council. Toward Precision Medicine: Building a Knowledge Network for Biomedical Research and a New Taxonomy of Disease. Washington, DC: The National Academies Press; 2011 . Available from: https:// doi.org/10.17226/13284.

2. NEWS from the National Academies. Report Calls for Creation of a Biomedical Research and Patient Data Network For More Accurate Classification of Diseases, Move Toward 'Precision Medicine'. Nov 2, 2011. Available from: http://www8.nationalacademies.org/onpinews/ newsitem. aspx? recordid $=1328$

3. Glicksberg BS, Johnson KW, Dudley JT. The Next Generation of Precision Medicine: Observational Studies, Electronic Health Records, Biobanks and Continuous Monitoring. Human Molecular Genetics. 2018 May 1;27(R1):R56-R62. doi: $10.1093 / \mathrm{hmg} /$ ddy 114.

4. Population Trends. United Nations Population Fund. Available from: https://asiapacific.unfpa.org/en/node/15207

5. United Nations ESCAP. Population Trends in Asia and the Pacific. Nov 2013. Available from: http://www.unescapsdd.org/files/documents/SPPS-Factsheet-PopulationTrends-v3.pdf
6. World Health Organization. Global Health Observatory website. Cited 2014 April 21 . Available from: http://apps. who.int/gho/data/node.country.

7 Dementia in Asia Pacific Region. Alzheimer's Disease International, London, November 2014.

cc) Open Access This article is licensed under a Creative Commons Attribution 4.0 Internationa License, which permits use, sharing, adaptation, distribution and reproduction in any medium or format, as long as you give appropriate credit to the original author(s) and the source, provide a link to the Creative Commons license, and indicate if changes were made. The images or other third party material in this article are included in the article's Creative Commons license, unless indicated otherwise in a credit line to the material. If material is not included in the article's Creative Commons license and your intended use is not permitted by statutory regulation or exceeds the permitted use, you will need to obtain permission directly from the copyright holder. To view a copy of this license, visit http://creativecommons.org/licenses/ by/4.0/. 